\author{
Matej URBANSKÝ ${ }^{1}$, Peter KAŠŠAY², Jozef KRAJŇÁK ${ }^{3}$ \\ Supervisor: Robert GREGA ${ }^{4}$
}

DOI: https://doi.org/10.53052/9788366249837.25

\title{
PNEUMATYCZNE ELASTYCZNE SPRZĘGLO TŁOKOWE MAJĄCE ZASTOSOWANIE W PRZEMYŚLE SAMOCHODOWYM
}

Streszczenie: W artykule przedstawiono nowo opracowane pneumatyczne sprzęgło elastyczne tłokowe, które znajduje zastosowanie w przemyśle samochodowym jako dwumasowe koło zamachowe. Jego konstrukcja koncentruje się na wykonaniu wysoce elastycznego sprzęgła, o bardzo niskiej względnej sztywności skrętnej. Sprzęgło jest chronione patentem.

Słowa kluczowe: pneumatyczne sprzęgło elastyczne, wysoce elastyczne sprzęgło, dwumasowe koło zamachowe, przemysł samochodowy

\section{PiSTON PNEUMATIC FLEXIBLE SHAFT COUPLING APPLICABLE IN THE AUTOMOTIVE INDUSTRY}

Summary: The paper presents a newly developed Piston pneumatic flexible shaft coupling, which is applicable in the automotive industry as a dual-mass flywheel. Its design is focused on creating the high-flexible coupling, which means flexible coupling with very low value of relative torsional stiffness. The coupling is protected by means of a patent.

Keywords: pneumatic flexible shaft coupling, high-flexible coupling, dual-mass flywheel, automotive industry

\section{Introduction}

Nowadays, flexible shaft couplings are the most utilized machine parts for the flexible transmission of load torque in machines with rotary power transmission, mainly in order to avoid dangerous torsional vibration in the systems. Therefore, a flexible

\footnotetext{
${ }^{1}$ Technical University of Košice; Faculty of Mechanical Engineering, Department of Machine Design and Transport Engineering; Matej.Urbansky@tuke.sk

${ }^{2}$ Technical University of Košice; Faculty of Mechanical Engineering, Department of Machine Design and Transport Engineering; Peter.Kassay@tuke.sk

${ }^{3}$ Technical University of Košice; Faculty of Mechanical Engineering, Department of Machine Design and Transport Engineering; Jozef.Krajnak@tuke.sk

${ }^{4}$ prof. Ing., CSc.; Technical University of Košice; Faculty of Mechanical Engineering;

Department of Machine Design and Transport Engineering; Robert.Grega@tuke.sk
} 
coupling with suitable dynamic properties, particularly dynamic torsional stiffness, has to be carefully chosen for each specific application, e.g. [2-5, Błąd! Nie można odnaleźć źródła odwołania.-8, 10].

Flexible elements of flexible shaft couplings are made of various materials, mainly of rubber, plastic and metal. During the operation of mechanical systems, it comes particularly to the fatigue and ageing of rubber and plastic flexible elements and to the ageing and wearing down of the metal flexible elements of applied flexible coupling, e.g. [1,8]. Consequently, the applied flexible coupling loses its original dynamic properties and thus the ability to carry out its important functions in a torsionally oscillating mechanical system (TOMS), mainly the tuning of a mechanical system in terms of torsional dynamics. The disadvantages of the mentioned flexible elements can be eliminated using pneumatic flexible elements, for example air springs, e.g. [6,9]. The flexible transmission of torque is ensured by compressed gaseous medium, which do not suffer from fatigue or ageing. The main advantage of pneumatic flexible shaft couplings (for example Fig.1) is the possibility to change their torsional stiffness which depends on the gaseous medium pressure value in its pneumatic flexible elements. This makes it possible to suitably adapt the dynamic torsional stiffness of a pneumatic coupling to the actual operating mode of a mechanical system.

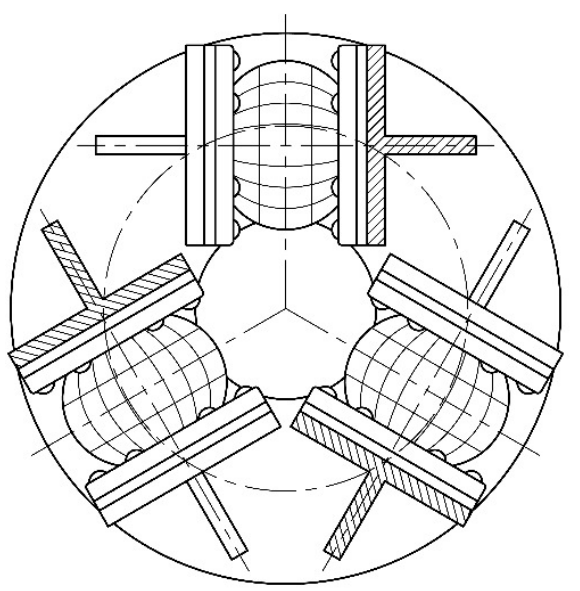

a)

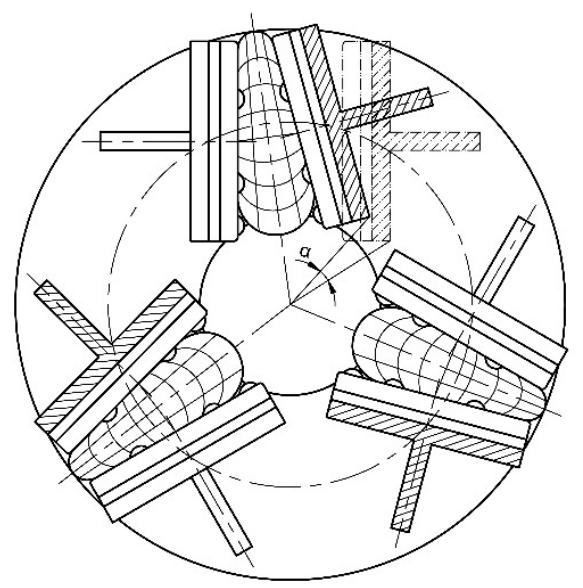

b)

Figure 1. A tangential pneumatic flexible shaft coupling, a) in basic position, b) in fully loaded state (at maximum twist angle $\alpha$ )

At our department, we deal with development, research and application of pneumatic flexible shaft couplings into mechanical systems. We focus mainly on continuous tuning of mechanical systems during their operation in terms of torsional dynamics using pneumatic flexible shaft couplings as active torsional vibration tuners. For the continuous tuning, we use electronic control systems, developed by us. Our extensive research in the field of pneumatic torsional vibration tuners and torsional dynamics also leads to improvements of our pneumatic tuners and control systems, e.g. [2-5]. In order to improve the tuners in terms of better utilization of their pneumatic flexible elements and achieving specific operational properties, a new Piston pneumatic tuner 
was designed. The aim of this article is to introduce this new pneumatic tuner, protected by means of the patent ${ }^{5}$, namely the Piston pneumatic flexible shaft coupling. Due to the reason that mentioned pneumatic tuner is not manufactured yet, this article deals mainly with principles and expected advantages of the tuner.

\section{Proposed flexible shaft coupling}

Proposed piston pneumatic flexible shaft coupling (Fig.2, Fig.3, Fig.4) is made up of a driving flange (1), driven flange (2), pneumatic flexible elements (4), curved hollow cases (5), curved piston bodies (3), fastening flanges (6) and valves (7). The compression volume of the coupling is created of two pneumatic flexible elements (4), which are placed motionlessly in the hollow cases (5), which are attached to the driven flange (2). The piston bodies (3) are attached to the driving flange (1). The pneumatic flexible elements (4) are inflated to required overpressure of gaseous media through the valves (7) and the basic position of the piston bodies and the driving flange (1) in relation to the driven flange (2) is herewith defined (Fig.2).

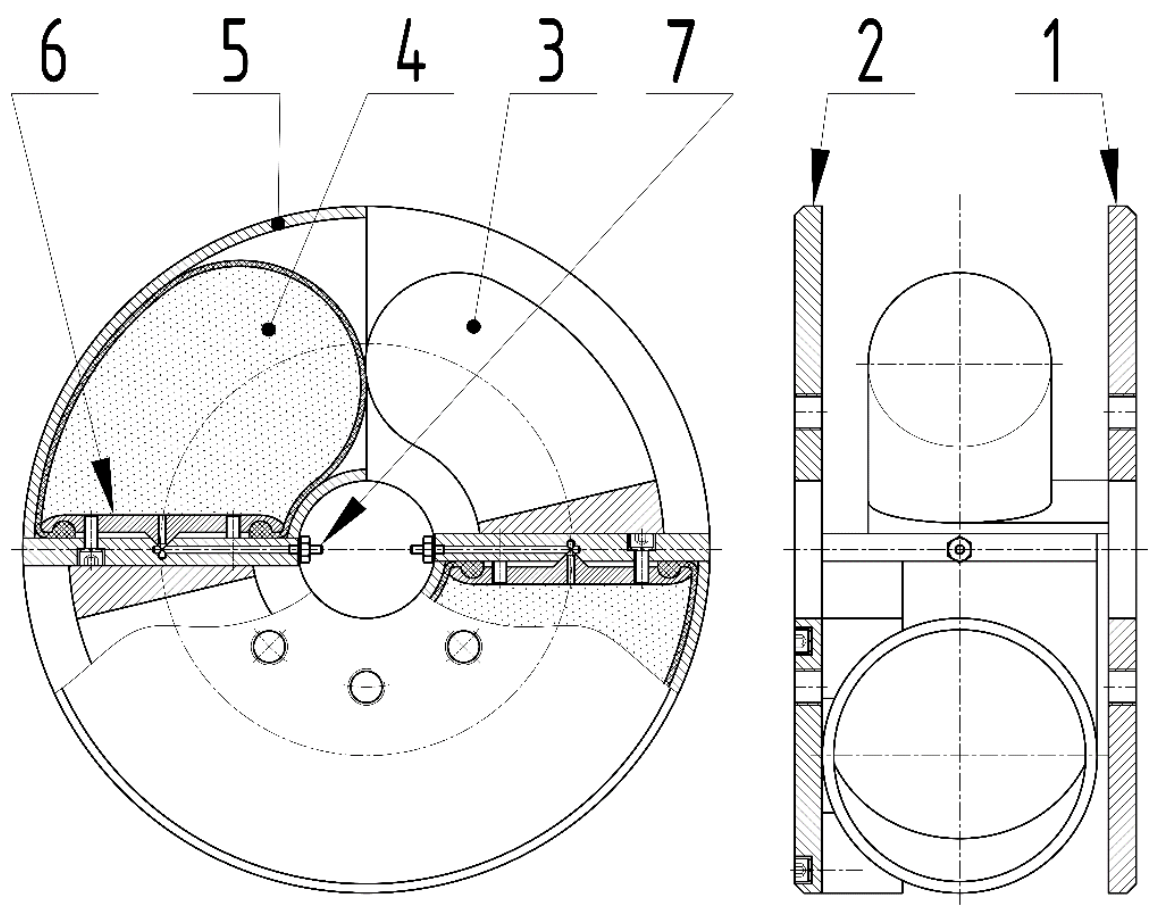

Figure 2. The piston pneumatic flexible shaft coupling of type 2-1/110-P-C in unloaded state

${ }^{5}$ Urbanský Matej, Homišin Jaroslav. 2016. Piston pneumatic flexible shaft coupling. Patent No. SK 288390 B6. Banská Bystrica: ÚPV SR. 4 p. 
The transmission of a load torque causes the twist of the driving flange (1) in relation to the driven flange (2) and the piston bodies (3) are therefore pushed into the pneumatic flexible elements (4) so that the piston bodies (3) are coated with the pneumatic flexible elements (4) (Fig.3).

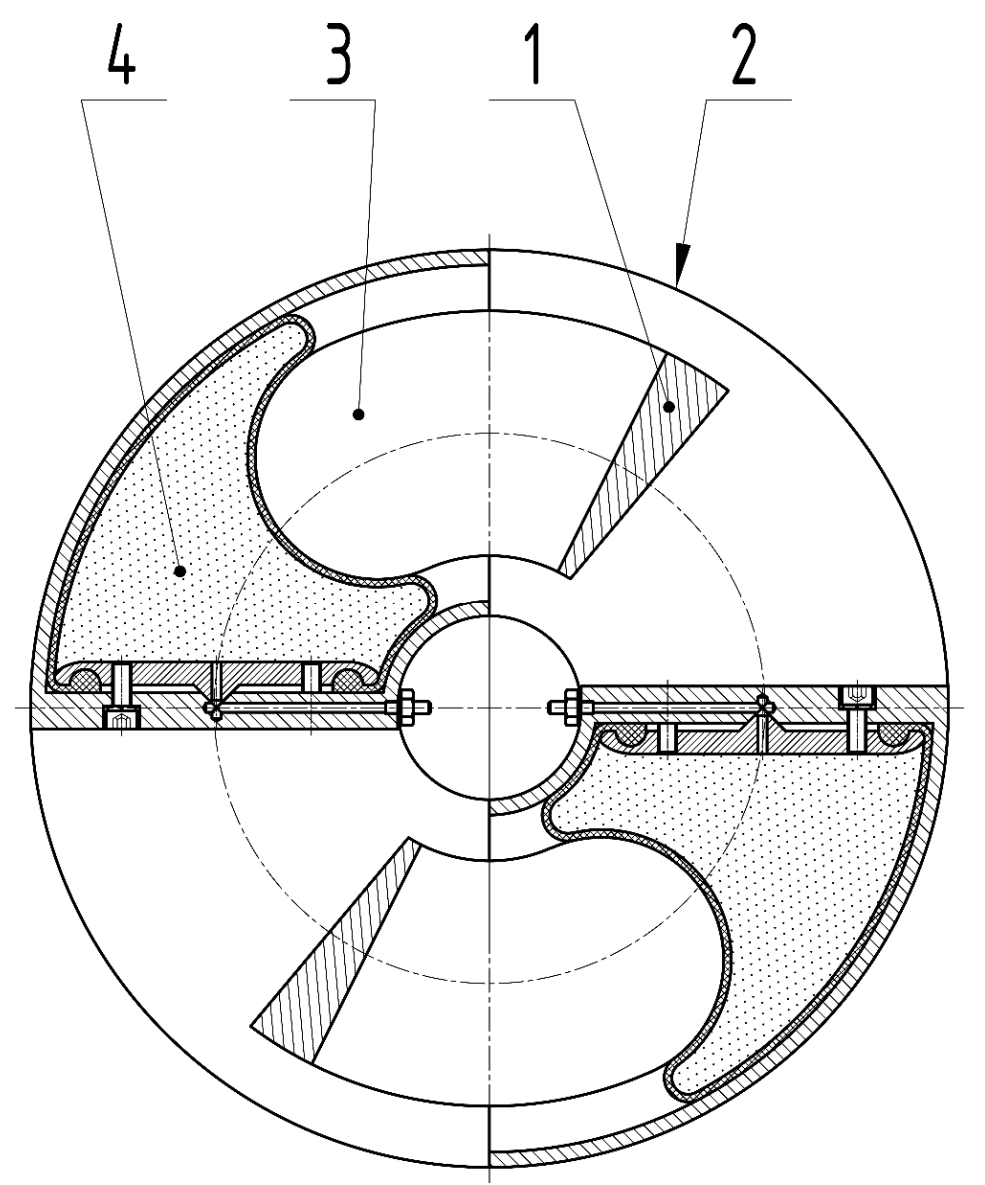

Figure 3. The piston pneumatic flexible shaft coupling of type 2-1/110-P-C in a partially loaded state

The design of the coupling allows its maximum angle of twist of $\alpha=75$ degrees (Fig.4), however, the coupling is able to transmit a load torque flexibly only in one direction. 


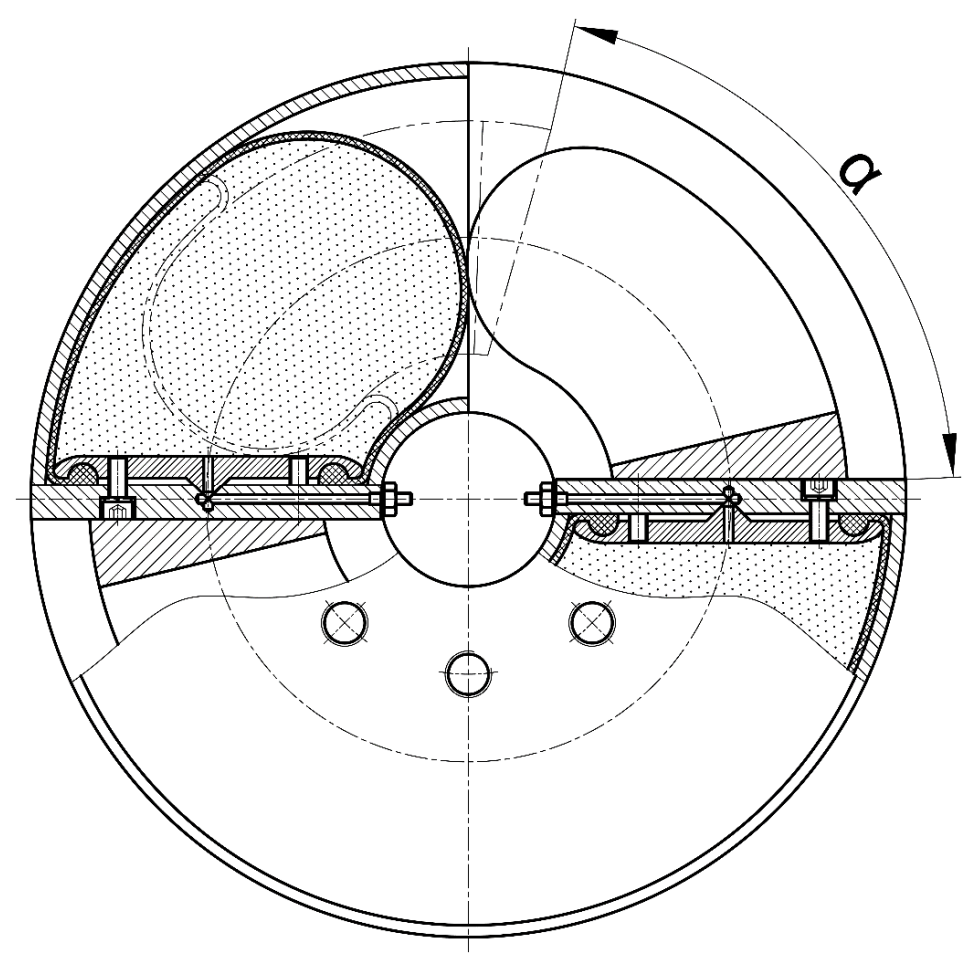

Figure 4. The maximum twist angle of the piston pneumatic flexible shaft coupling of type 2-1/110-P-C

\section{Conclusion}

The piston pneumatic flexible shaft coupling can be applied in systems of mechanical drives. It allows flexible torque transmission and thanks to the ability to change its torsional stiffness, ensure the tuning of these systems at various operating conditions. The design of the piston pneumatic flexible shaft coupling is focused on creating the high-flexible coupling. The current trend in the field of flexible shaft couplings, the most noticeable in automotive industry, is just the development and utilization of high-flexible couplings as dual mass flywheels. Because gaseous media throughout its lifetime is not subject to ageing, resulting that pneumatic couplings do not lose their initial positive dynamic properties, it seems to be very advantageous to develop flexible couplings with the advantages of both pneumatic and high-flexible couplings.

\section{Acknowledgement.}

This paper was written within the framework of grant project: VEGA 1/0528/20: „Solution of new elements for mechanical system tuning“. 


\section{REFERENCES}

1. GURSKÝ P.: Influence of working cycles identification on characteristics of flexible couplings and their comparison. PhD thesis, Košice, Slovakia: Technical University of Košice 2011.

2. HOMIŠIN J.: Characteristics of pneumatic tuners of torsional oscillation as a result of patent activity. Acta Mechanica et Automatica 10(2016)4: 316-323. ISSN 1898-4088. DOI: 10.1515/ama-2016-0050.

3. HOMIŠIN J.: Contribution and perspectives of new flexible shaft coupling types - pneumatic couplings. Scientific Journal of Silesian University of Technology.

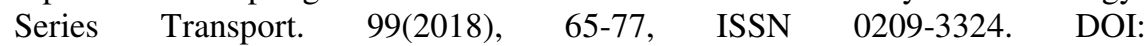
https://doi.org/10.20858/sjsutst.2018.99.6.

4. HOMIŠIN J.: Dostrajanie układów mechanicznych drgających skrętnie przy pomocy sprzęgieł pneumatycznych. [In Polish: Tuning methods of torsional oscillating mechanical systems by pneumatic couplings]. Bielsko-Biała: ATH 2008. ISBN 978-83-60714-55-3.

5. HOMIŠIN J.: Nové typy pružných hriadel'ových spojok: Vývoj-VýskumAplikácia. [In Slovak: New Types of Flexible Shaft Couplings: DevelopmentResearch-Application]. Košice: Vienala 2002. ISBN 80-7099-834-2.

6. IMI. „Compact air bellows”. Accessed: 30.09.2019. Available at: https://www.imi-precision.com/uk/en/list/actuators/air-bellows

7. LIPTAI P., MORAVEC M., LUMNITZER E., GERGELOVÁ M.: Proposal of the sound insulating measures for a vibrational sorter and verification of the measured effectiveness. Advances in Science and Technology-Research Journal 11(2017)3, 196-203. ISSN 2299-8624. DOI: 10.12913/22998624/76068.

8. MALÁKOVÁ S., HOMIŠIN J.: Defining of material characteristics for flexible element in pneumatic flexible coupling. In Projektowanie, badania i eksploatacja Tom 1, edited by Jacek Rysiński, 277-282. Poland: Wydawnictwo Naukowe Akademii Techniczno-Humanistycznej w Bielsku-Białej 2018. ISBN 978-83-65182-93-7.

9. RUBENA: Air Springs. Accessed: 30.09.2019. Available at: https://www.rubena.eu/underwood/download/files/rubena_vlnovce_trelleborg_2 019.pdf

10. STURM M., PEŠÍK L.: Determination of a Vibrating Bowl Feeder Dynamic Model and Mechanical Parameters. Acta Mechanica et Automatica 11(2017)3, 243-246. ISSN 1898-4088. DOI: 10.1515/ama-2017-0038. 